\title{
Front Matter: Volume 9206
}

, "Front Matter: Volume 9206," Proc. SPIE 9206, Advances in Metrology for XRay and EUV Optics V, 920601 (7 October 2014); doi: 10.1117/12.2084726

SPIE Event: SPIE Optical Engineering + Applications, 2014, San Diego, California, SPIE. United States 


\section{PROCEEDINGS OF SPIE}

\section{Advances in Metrology for X-Ray and EUV Optics V}

Lahsen Assoufid

Haruhiko Ohashi

Anand Krishna Asundi

Editors

18 August 2014

San Diego, California, United States

Sponsored and Published by

SPIE 
The papers included in this volume were part of the technical conference cited on the cover and title page. Papers were selected and subject to review by the editors and conference program committee. Some conference presentations may not be available for publication. The papers published in these proceedings reflect the work and thoughts of the authors and are published herein as submitted. The publisher is not responsible for the validity of the information or for any outcomes resulting from reliance thereon.

Please use the following format to cite material from this book:

Author(s), "Title of Paper," in Advances in Metrology for X-Ray and EUV Optics V, edited by Lahsen Assoufid, Haruhiko Ohashi, Anand Krishna Asundi, Proceedings of SPIE Vol. 9206 (SPIE, Bellingham, WA, 2014) Article CID Number.

ISSN: 0277-786X

ISBN: 9781628412338

Published by

SPIE

P.O. Box 10, Bellingham, Washington 98227-0010 USA

Telephone +1 3606763290 (Pacific Time) · Fax +1 3606471445

SPIE.org

Copyright (c) 2014, Society of Photo-Optical Instrumentation Engineers.

Copying of material in this book for internal or personal use, or for the internal or personal use of specific clients, beyond the fair use provisions granted by the U.S. Copyright Law is authorized by SPIE subject to payment of copying fees. The Transactional Reporting Service base fee for this volume is $\$ 18.00$ per article (or portion thereof), which should be paid directly to the Copyright Clearance Center (CCC), 222 Rosewood Drive, Danvers, MA 01923. Payment may also be made electronically through CCC Online at copyright.com. Other copying for republication, resale, advertising or promotion, or any form of systematic or multiple reproduction of any material in this book is prohibited except with permission in writing from the publisher. The CCC fee code is 0277-786X/14/\$18.00.

Printed in the United States of America.

Publication of record for individual papers is online in the SPIE Digital Library.

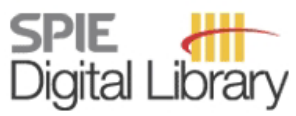

SPIEDigitalLibrary.org

Paper Numbering: Proceedings of SPIE follow an e-First publication model, with papers published first online and then in print and on CD-ROM. Papers are published as they are submitted and meet publication criteria. A unique, consistent, permanent citation identifier (CID) number is assigned to each article at the time of the first publication. Utilization of CIDs allows articles to be fully citable as soon as they are published online, and connects the same identifier to all online, print, and electronic versions of the publication. SPIE uses a six-digit CID article numbering system in which:

- The first four digits correspond to the SPIE volume number.

- The last two digits indicate publication order within the volume using a Base 36 numbering

system employing both numerals and letters. These two-number sets start with 00, 01, 02, 03, 04, $05,06,07,08,09,0 A, 0 B \ldots 0 Z$, followed by 10-1Z, 20-2Z, etc.

The CID Number appears on each page of the manuscript. The complete citation is used on the first page, and an abbreviated version on subsequent pages. Numbers in the index correspond to the last two digits of the six-digit CID Number. 


\title{
Contents
}

\author{
$\checkmark$ Authors \\ vii Conference Committee
}

\section{SESSION 1 SLOPE PROFILERS}

920602 A new optical head tracing reflected light for nanoprofiler [9206-1]

920603 The developmental long trace profiler (DLTP) optimized for metrology of side-facing optics at the ALS [9206-2]

920604 Upgrade of surface profiler for x-ray mirror at SPring-8 [9206-4]

920605 Ultra-high-precision surface processing techniques for nanofocusing ellipsoidal mirrors in hard x-ray region [9206-5]

920606 Design consideration for nano-accuracy long trace profiler at BSRF [9206-6]

\section{SESSION 2 AT-WAVELENGTH METROLOGY}

920607 A reflectometer for at-wavelength characterization of XUV-reflection gratings [9206-7]

920608 At-wavelength metrology of $x$-ray optics at Diamond Light Source [9206-8]

\section{SESSION $3 \quad$ MICROSCOPES/FIGURE INTERFEROMETERS}

9206 OD An extreme ultraviolet interferometer suitable to generate dense interference pattern [9206-13]

9206 OE Experimental results for absolute cylindrical wavefront testing [9206-14]

\section{SESSION 4 EXTREME ANGLE MEASUREMENTS AND CALIBRATION}

9206 OF Pushing the limits: latest developments in angle metrology for the inspection of ultraprecise synchrotron optics (Invited Paper) [9206-15]

9206 OG Angular calibration of surface slope measuring profilers with a bendable mirror [9206-16]

$9206 \mathrm{OH}$ Design of a precision two-dimensional tip-tilting stage system for autocollimator-based long trace profiler angular calibration [9206-17] 


\section{SESSION 5 FACILITIES}

9206 Ol A new x-ray optics laboratory (XROL) at the ALS: mission, arrangement, metrology capabilities, performance, and future plans (Invited Paper) [9206-18]

9206 0J An XUV optics beamline at BESSY II [9206-19] 


\title{
Authors
}

Numbers in the index correspond to the last two digits of the six-digit citation identifier (CID) article numbering system used in Proceedings of SPIE. The first four digits reflect the volume number. Base 36 numbering is employed for the last two digits and indicates the order of articles within the volume. Numbers start with 00, 01, 02, 03, 04, 05, 06, 07, 08, 09, 0A, 0B...0Z, followed by 10-1Z, 20-2Z, etc.

\author{
Alatawi, Ayshah, OE \\ Alcock, Simon G., 08 \\ Anton, J., $\mathrm{OH}$ \\ Artemiev, Nikolay A., 03, 0G, Ol \\ Assoufid, L., $\mathrm{OH}$ \\ Berujon, Sebastien, 08 \\ Bischoff, P., 07 \\ Chow, Ken P., OG \\ Domning, Edward E., 03, OG \\ Eggenstein, F., 07, 0J \\ Endo, K., 02 \\ Erko, A., OJ \\ Follath, R., OJ \\ Frolov, O., OD \\ Gaupp, A., 07 \\ Geckeler, Ralf D., OF \\ Kearney, S., $\mathrm{OH}$ \\ Kishimoto, H., 04 \\ Kitayama, T., 02 \\ Kolacek, K., OD \\ Koyama, Takahisa, 05 \\ Kudo, R., 02 \\ Künstner, S., 0J \\ Lacey, Ian, 03, 0G, 0 \\ Li, Ming, 06 \\ Liu, W., $\mathrm{OH}$ \\ Mast, M., OJ \\ Matsuyama, Satoshi, 05 \\ McKinney, Wayne R., 03, 이 \\ Melich, R., OD \\ Miura, T., 04 \\ Morrison, Gregory Y., 03 \\ Morton, Simon A., 03 \\ Nakano, M., 02 \\ Ohashi, Haruhiko, 04, 05 \\ Okita, K., 02 \\ Okuda, K., 02 \\ Padmore, Howard A., 0 \\ Prukner, V., OD \\ Qian, J., $\mathrm{OH}$ \\ Reardon, Patrick J., OE \\ Sawhney, Kawal, 08 \\ Schäfers, F., 07, 0J \\ Schmidt, J. S., OJ \\ Schmidt, J., OD \\ Senba, Y., 04 \\ Senf, F., 07, OJ \\ Shu, D. OH \\ Siewert, Frank, OF, OJ
}

\author{
Smith, Brian V., 03, OG \\ Sokolov, A. A., 07, 0J \\ Straus, J., OD \\ Sullivan, J., $\mathrm{OH}$ \\ Sutter, John, 08 \\ Tang, Shanzhi, 06 \\ Tokuta, Y., 02 \\ Wang, Hongchang, 08 \\ Wang, Lichao, 06 \\ Wang, Qiushi, 06 \\ Yamamura, K., 02 \\ Yamauchi, Kazuto, 05 \\ Yandayan, Tanfer, OF \\ Yang, Fugui, 06 \\ Yashchuk, Valeriy $\vee ., 03,0 G, 01$ \\ Yumoto, Hirokatsu, 05 \\ Zeschke, T., 07, 0J
}




\section{Conference Committee}

Program Track Chair

Katherine Creath, Optineering (United States) and The Univ. of Arizona (United States)

Conference Chairs

Lahsen Assoufid, Argonne National Laboratory (United States)

Haruhiko Ohashi, Japan Synchrotron Radiation Research Institute (Japan)

Anand Krishna Asundi, Nanyang Technological University (Singapore)

Conference Program Committee

Simon G. Alcock, Diamond Light Source Ltd. (United Kingdom)

Raymond Barrett, European Synchrotron Radiation Facility (France)

Daniele Cocco, SLAC National Accelerator Laboratory (United States)

Leslie L. Deck, Zygo Corporation (United States)

Ralf D. Geckeler, Physikalisch-Technische Bundesanstalt (Germany)

Kenneth A. Goldberg, Lawrence Berkeley National Laboratory

(United States)

Mikhail V. Gubarev, NASA Marshall Space Flight Center

(United States)

Mourad Idir, Brookhaven National Laboratory (United States)

Weiguo Liu, Xi'an University of Technology (China)

Hidekazu Mimura, The University of Tokyo (Japan)

Josep Nicolas, CELLS - ALBA (Spain)

Rajdeep Singh Rawat, National Institute of Education (Singapore)

Mark D. Roper, Daresbury Laboratory (United Kingdom)

Kawal J. Sawhney, Diamond Light Source Ltd. (United Kingdom)

Frank Siewert, Helmholtz-Zentrum Berlin für Materialien und Energie GmbH (Germany)

Regina Soufli, Lawrence Livermore National Laboratory (United States)

Peter Z. Takacs, Brookhaven National Laboratory (United States)

Muriel Thomasset, Synchrotron SOLEIL (France)

Amparo Vivo, European Synchrotron Radiation Facility (France)

Zhanshan Wang, Tongji University (China)

Kazuto Yamauchi, Osaka University (Japan)

Tanfer Yandayan, TUBITAK UME (Turkey) 
Valeriy V. Yashchuk, Lawrence Berkeley National Laboratory (United States)

Brian W. Yates, Canadian Light Source Inc. (Canada)

\section{Session Chairs}

1 Slope Profilers

Haruhiko Ohashi, Japan Synchrotron Radiation Research Institute (Japan)

Valeriy V. Yashchuk, Lawrence Berkeley National Laboratory (United States)

2 At-wavelength Metrology

Kawal J. Sawhney, Diamond Light Source Ltd. (United Kingdom)

3 Microscopes/Figure Interferometers

Haruhiko Ohashi, Japan Synchrotron Radiation Research Institute (Japan)

4 Extreme Angle Measurements and Calibration

Frank Siewert, Helmholtz-Zentrum Berlin für Materialien und Energie GmbH (Germany)

Kawal Sawhney, Diamond Light Source Ltd. (United Kingdom)

$5 \quad$ Facilities

Lahsen Assoufid, Argonne National Laboratory (United States)

Daniele Cocco, SLAC National Accelerator Laboratory (United States) 